\title{
SELECTIVE TRANSFER IN THE ACQUISITION OF ENGLISH DOUBLE OBJECT CONSTRUCTIONS BY BRAZILIAN LEARNERS
}

\author{
Júlia Vidigal ZARA* \\ Fernando Luiz Pereira de OLIVEIRA* \\ Ricardo Augusto de SOUZA***
}

- ABSTRACT: The present study investigates the acquisition of the English double object constructions (GOLDBERG, 1995) by Brazilian learners. We hypothesize that, due to first language (L1) influences, the prepositional ditransitive construction (John gave a book to Mary) will be acquired earlier, while the ditransitive construction (John gave Mary a book) will be part of the learner's interlanguages (SELINKER, 1972) only at the advanced level of proficiency. We also hypothesize that learners may transfer (ODLIN, 1989) the placement of the object pronoun in pre-verbal position from their L1 to their interlanguage in early stages of acquisition (João me deu um livro / *John me gave a book). We test our hypotheses by comparing the performance of three groups of learners (beginning, intermediate, and advanced) and native speakers of English on an acceptability judgment task used as a measure of learnability and generalization. Results confirm the order of acquisition of the English double object constructions predicted for native speakers of Brazilian Portuguese. Moreover, results suggest that, although mother tongue influences may have taken place, they do not do so pervasively, but rather selectively, corroborating the proposal by Kellerman (1983).

- KEYWORD: Cross-linguistic influence. Selective transfer. Double object constructions. Bilingualism.

\section{Introduction}

The linguistic realizations of predicators - especially as expressed by verbs - and the arguments that accompany them to saturate a semantic configuration are taken as a central element of knowledge of language in several theoretical frameworks, such as Chomsky (1981), Goldberg (1995, 2006), Jackendoff

\footnotetext{
* UFMG - Universidade Federal de Minas Gerais. Faculdade de Letras. Belo Horizonte - MG - Brasil. $31270-901$ juliavzara@gmail.com

** UFOP - Universidade Federal de Ouro Preto. Instituto de Ciências Exatas e Biológicas - Departamento de Estatística. Ouro Preto - MG - Brasil. 35400-000 - fernandoluizest@gmail.com

*** UFMG - Universidade Federal de Minas Gerais. Faculdade de Letras. Belo Horizonte - MG - Brasil. 31270-901 - ricsouza@ufmg.br
} 
(2002), and Van Valin and Lapolla (1997). Taken as part of the architecture of grammar, argument realization may be regarded as the transition from mental representations of concepts - especially events - to their overt manifestations as morphosyntactic structures. Therefore, argument structure is a domain of grammar where conceptual meaning, morphophonological realization and syntactic structures clearly interface. Since argument structure patterns are the by-product of the linguistic coding of event construal, and because the expression of events seems to be a pervasive goal in human communicative activity, we understand the acquisition of argument structure patterns as a central feature of both first and second language learning.

Since the late 1990s there has been growing interest among Second Language Acquisition researchers in how argument structure is represented by speakers of non-native languages (JUFFS, 2000; WHITE, 2003). Second language argument structure research has explored different types of constructions and transitivity configurations for different types of predicators, especially verbs. Findings in this branch of $\mathrm{L} 2$ research converge in framing the acquisition of non-native argument structure as a potential challenge for L2 learners, a fact not at all surprising when the wide cross-linguistic variability in argument realization is considered (LEVIN; HOVAV, 2005; CULICOVER, 2009).

The present study aims at contributing to second language argument structure studies with empirical findings about Brazilian Portuguese L1-English L2 learners. Specifically, we focus on the L2 acquisition of English double object constructions. Such constructions involve verbs that lexicalize a meaning of caused possession - for example, give - or they lexicalize a convergence of both a meaning of caused possession and a meaning of caused motion - such as send (HOVAV; LEVIN, 2008). Because of mismatches between the syntactic realization of this type of predicate in the L1 and L2 of the learners in our study, there are linguistically plausible hypotheses concerning overgeneralizations and undergeneralizations that may impinge on their L2 representations. In this article we report an experimental test of such hypotheses, and we discuss the findings in light of their implications for theoretical models of the nature of L2 knowledge.

The next two sections lay the theoretical and descriptive foundations for the present study, leading to the explicit statement of the four hypotheses that we sought to test. Afterwards, we provide details about the design of the empirical study, followed by the results of the statistical analyses of the data. We then move on to a discussion of our findings. We conclude the article exploring some consequences of the study with respect to the theoretical framework upon which it is based. 


\section{Cross-linguistic influences and L2 argument realization}

L1 influences on L2 learning is certainly a phenomenon amply known by second language and bilingualism researchers of all theoretical persuasions. The study of such influences is at the heart of important theoretical debates over the first decades of modern second language acquisition research. The phenomenon's wide acceptance notwithstanding, disputes over the precise extent to which learners' L1 has a role in the ultimate form of their L2 have always been a central issue in Second Language Acquisition research and in models of L2 learning and use (ODLIN, 1989; ELLIS, 2008). Hypotheses about such role of the first language have ranged from proposals that the L1 was the single most important learnerexternal variable to the denial that it could be a significant variable, being at best secondary to universal routes of language development.

In Selinker's (1972) original proposal of "interlanguage" as a theoretical construct, the concept of "language transfer" is proposed to acknowledge the phenomenon of L1 influences in second language learning. Such metaphor was an important theoretical move from the then dominant concept of "interference", as the latter clearly implied that L1 influences were generally only an impediment to an otherwise reasonably straightforward L2 development. In Selinker's theory, language transfer is framed as one of the motivating cognitive elements of the singularities of L2 learners' knowledge of the target language, together with overgeneralization of L2 patterns, employment of learning and communication strategies, and language training effects.

From a learner-centered perspective, L1 knowledge may be viewed as schemata mediating between the L2 input and target language representations. Schachter (1993) explicitly frames language transfer as part of the L2 learner's process of building and testing conscious or unconscious hypotheses about the target language. According to her view, as the learner experiences communication in the target language, she may rely more or less explicitly on the linguistic schemata provided by her knowledge of the L1. When critical features of L1 and L2 coincide, L1 influences will be facilitative, thus resulting in "positive transfer". On the other hand, divergence across critical features of both languages may lead to temporary or permanent representations that do not match the L2 input, hence "negative transfer".

L1 transfer may not be a mandatory mechanism affecting the whole of L2 learning, though. For example, Kellerman $(1979,1983)$ suggests that language transfer is constrained by either tacit or explicit impressions of how transparent or opaque structures are cross-linguistically. In other words, according to Kellerman's view, L2 learners activate, or rely on knowledge of their L1 on a selective basis, guided by intuitions of which features of their previous language experience 
might plausibly match corresponding features in the target language. Such learners' explicit or subliminal perceptions of how compatible a structure from a dominant or prior language is with a new language being acquired was referred to by Kellerman (1983) as "psychotypology". As emphasized in Kellerman (1983), the notion of psychotypology highlights a cognitive mechanism that outreaches actual form-function correspondences across languages, as he poses that the "[... [ [g]eneral typological closeness of L1 and L2 [is] capitalized on by learners as the result of a relatively immediate opportunity to identify cognate forms and structures across languages." (KELLERMAN, 1983, p.114). Therefore, what the concept of psychotypology seeks to describe is a situation in which it is the perceived identity of structures between languages, rather than actual identity, that modulates language transfer. Psychotypology as a cognitive factor in language transfer was explored by Rothman and Cabrelli Amaro (2010). The authors analyzed the null-subject parameter among learners of French L3 who were bilingual speakers of English L1 and Spanish L2. The authors' findings suggest that L2 blocks L1 transfer effects, but they highlight that their results could be explained by psychotypologically motivated transfer, as conceptualized in Kellerman (1983).

Ultimately, the extent to which L1 knowledge affects L2 representations, the circumstances and domains in which it does play a significant role, and the mechanisms involved in the possible inhibition of L1 effects is a still largely unresolved issue in the study of second language acquisition and bilingualism. It certainly is nevertheless a critical aspect for any comprehensive theoretical model of second language acquisition and L2 representations.

Second language learning and bilingualism literature provides abundant evidence that a second language speaker's L1 may significantly affect her L2 knowledge of argument structure, both for the production and for the comprehension of syntactic expressions of argument role relationships. Nevertheless, the issue remains of empirical - and ultimately theoretical - interest precisely because of the oftentimes subtle cross-linguistic differences in the conceptual conflations subsumed not only in a given verb, for example, but also in the range of meanings entailed by argument structure constructions (GOLDBERG, 1995, 2006). Therefore, observation of the acquisition of a given language's argument structure patterns (or lack thereof) by adult learners from different linguistic backgrounds can provide linguists with empirical evidence of the lexical-semantic underpinnings of knowledge of argument realization in morphosyntax, as well as provide them with insights about the machinery of L1-based generalizations that may constrain productive and reasonably stable form-meaning pairings in the L2.

At present, second language argument structure research encompasses evidence from a variety of bilingual configurations. The language backgrounds and language learning scenarios investigated encompass an array of language 
families. Processing studies, for instance, strongly suggests cross-linguistic effects on parsing of L2 structures instantiating causative-inchoative alternation (JUFFS, 1998) among learners of English whose linguistic backgrounds were Korean, Japanese, Chinese, and three Romance languages. Evidence for unaccusativity is discussed by Montrul (2004) on the basis of processing data from English learners of L2 Spanish, and priming of double object structures among L1 Greek and L2 English bilinguals are reported in Salamoura and Williams (2007). Instances of production data showing L1 morphosyntactic restrictions for intransitive verbs impinging on L2 English were examined in Balcom (1997) - for L1 Chinese; and Oshita (2000) - a corpus-based study of learners of English of Italian, Spanish, Japanese and Korean backgrounds. The present study is a supplement to current work on matters of L2 argument structure involving bilinguals whose L1 is Brazilian Portuguese, such as Vilela and Oliveira (2010), and Souza (2011) on issues of grammatical representation of subject as beneficiary constructions and induced movement constructions respectively; and Souza and Oliveira (2011) on matters of language processing of induced movement constructions. Moreover, to the extent of our knowledge, the present study is innovative with respect to Brazilian Portuguese-English learners because of its focus on the dative construction in particular.

We now move on to the description of the expression of transfer of possession in Brazilian Portuguese, demonstrating that despite some surface overlap, the constructions of Portuguese abide by constraints that conflict with their counterparts in English. From the descriptive facts discussed in the next section, we will derive the specific hypotheses tested in the present study.

\section{Background to double object constructions in Brazilian Portuguese}

Double object alternation, also called dative alternation, is both a frequent phenomenon of English and a feature of its grammar often described by linguists (GOLDBERG, 1995; JACKENDOFF, 2002; HOVAV; LEVIN, 2008; CULICOVER, 2009). English verbs taking double objects may occur in constructions in which the verb is followed by a direct object (hence an NP) and a prepositional phrase (hence a preposition head followed by an object NP). Also, they may occur in constructions in which the verb is followed by two NPs, where the object of the prepositional phrase is usually thought of as having been "extracted" from it, with the preposition head having been deleted. The former is illustrated in sentence one and the second in sentence two below:

(1) Mary gave a box of candy to John. - Prepositional ditransitive construction.

(2) Mary gave John a box of candy. - Ditransitive Construction. 
The term "alternation" highlights the fact that sentences (1) and (2) can be construed is near paraphrases. In the theoretical framework of thematic roles and theta-theory (JACKENDOFF, 1972; CHOMSKY, 1981), the NP a box of candy is described as theta-marked "theme", and the NP John is describe as thetamarked "goal". The label "dative alternation" thus profiles that the object of the preposition (the goal role), or dative, undergoes derivational procedures that make it alternate positions with the direct object of the verb (the theme role). This account somehow entails a view that sentence (1) is more basic - in the sense of being more intrinsically related to the semantic interpretation of the both sentences - than is sentence (2), an account critically reviewed in more detail elsewhere (GOLDBERG, 2006; JACKENDOFF; CULICOVER, 2006). A terminological byproduct of the alternation viewpoint is reference to the non-prepositional phrase goal object "John" in sentence (2) as a "dativized" object.

Dativized double object constructions are far more restricted in Brazilian Portuguese (BP) than they are in English. In BP, usually, if the goal or beneficiary role is realized by a non-pronominal NP, such NP has to be the object of an overt preposition, therefore not typically allowing for dativization. This is actually the only accepted form of the double object constructions in standard BP as it is described in traditional grammars of the language, such as Bechara (2003). According to this grammarian, sentences such as the following are typical exemplars of double object constructions with non-pronominal goal/beneficiary NPs in Brazilian Portuguese (BECHARA, 2003)1.

(3) O diretor escreveu cartas aos pais.

The headmaster-Masc-Sg writePAST-3 ${ }^{\text {rd }}$ letter-Pl to-the-Masc-Pl parent-Pl. The headmaster wrote letters to the parents. / The headmaster wrote the parents letters.

(4) Enviaram o presente à professora.

PRO sendPAST-3 $3^{\text {rd }}-\mathrm{Pl}$ the gift-Masc-Sg to-the-Fem-Sg teacher-Fem-Sg

They sent the gift to the teacher. / They sent the teacher the gift.

This state of things is different when the goal or beneficiary role is realized by a pronominal NP. In such circumstances, the pronominal NP may be realized as the object of an overt preposition, but it may also cliticize with the verb, in which case it may generally occur post- or pre-verbally. In other words, Brazilian Portuguese allows for a double object construction configured with a pre-verbal pronoun (BECHARA, 2003), a position not licensed in English. This is illustrated below:

Sentence (3) was extracted from Bechara (2003, p.421). Sentences (4) through (7) are adapted from analyses developed in the ensuing pages of the same text. 
(5) O diretor escreveu cartas a eles.

The headmaster-Masc-Sg writePAST-3 ${ }^{\text {rd }}$ letter-Pl to PRN- $3^{\text {rd }}-\mathrm{Pl}$.

The headmaster wrote letters to them. / The headmaster wrote them letters.

(6) O diretor escreveu-lhes cartas.

The headmaster-Masc-Sg writePAST-3 ${ }^{\text {rd }}-\mathrm{PRN}-3^{\text {rd }}-\mathrm{Pl}-\mathrm{Dat}$ letter-Pl.

The headmaster wrote them letters.

(7) O diretor lhes escreveu cartas.

The headmaster-Masc-Sg PRN-3 ${ }^{\text {rd }}-P l-D a t$ writePAST-3 ${ }^{\text {rd }}$ letter-Pl.

* The headmaster them wrote letters.

The headmaster wrote them letters.

As a pre-verbal goal/beneficiary pronoun is not a syntactic alternative in English, the syntax of Portuguese offers the option of one more position for pronoun placement in double object constructions when compared with the syntax of English.

However, the description of double object constructions in Brazilian Portuguese may be far more complex when what happens in certain regional varieties of spoken BP is also considered. As observed by Scher (1996) and Gomes (2003), there are varieties of spoken Brazilian Portuguese in which dativized double object constructions may be considered an emerging syntactic configuration ${ }^{2}$. According to these authors, there is reasonable acceptability, at least for speakers of some dialects of BP, of sentences such as the following ones (data from utterances observed by the first author of the present article in speech of native speakers of BP from the region where the three authors live):

(8) Dá o papai a batata

Give the-Masc-Sg daddy-Masc-Sg the-Fem-Sg potato-Fem-Sg.

Give daddy the chips.

(9) Posso oferecer a Ana Júlia o biscoito?

May PRO offer the-Fem Ana Júlia the-Masc cookie-Masc-Sg

May I offer Ana Júlia some cookies?

The accounts of Scher (1996) and Gomes (2003) suggest that such sentences exemplify a syntactic realization of the ditransitive construction that is increasingly more accepted in varieties of Portuguese spoken in central Brazil (such as the states of Minas Gerais and Goiás). Also, it may be the case that dativized double object constructions in BP are sociolinguistically marked, associated with reasonable levels of familiarity and between interlocutors - as

2 These authors apparently did not rely on electronic corpora analyses in the references cited here. 
in conversations between child and care-takers or within families - the specific case of utterances (8) and (9) above.

Although there is some overlap in the surface manifestation of the double object construction in Portuguese and in English, especially when dialects from central Brazil are considered, the former language has restrictions on forms of the construction that conflict with what is permitted in English. Such complexity allows us to hypothesize that the acquisition of the construction by speakers of Brazilian Portuguese L1 may constitute a learning challenge. When acquiring ditransitives in L2 English, those learners will need to find out not only which verbs are accepted in the dativized double object construction in the target language, but they will also need to overrule constraints and restrictions from their L1 grammar and usage patterns.

Assuming the view that language transfer, or activation of L1 knowledge over the course of L2 learning and use, is a plausible and possible phenomenon among language learners and bilinguals, we hypothesized four possible scenarios for Brazilian Portuguese L1 learners of English L2 acquiring the English double object constructions:

Hypothesis 1: The English ditransitive construction, He gave John a book/ Ele deu João um livro, restricted in Brazilian Portuguese, will impose learning difficulties for learners.

Hypothesis 2: Due to analogy between sentences like Ele deu-me um livro in Brazilian Portuguese and He gave me a book in English, the dativized pronoun $<$ recipient> will not impose learning difficulties for learners.

Hypothesis 3:The expression of the $<$ recipient $>$ pronoun in pre-verbal position, *He me gave a book/Ele me deu um livro, which is possible in Brazilian Portuguese but ungrammatical English, may be transferred to the interlanguage of beginning learners.

Hypothesis 4: The prepositional ditransitive construction, He gave a book to Mary/Ele deu um livro para Maria, present in both L1 and L2, will not impose learning difficulties for learners.

These hypotheses led us to design a study that sought to investigate the nature of Brazilian Portuguese L1-English L2 bilinguals' representations of dative constructions in English at different stages in their L2 development. We now pass over to a description of the experiment by way of which we tested such hypotheses. 


\section{The study}

\section{Participants}

A total of 62 Brazilian Portuguese native speakers residing in the state of Minas Gerais (central Brazil) participated in the study. They were divided into three experimental groups according to their scores on an English placement test $^{3}$ : 25 beginning English learners (beginning experimental group - mean age 29.8 years), 22 intermediate English learners (intermediate experimental group - mean age 26.4 years), and 15 EFL teachers (advanced experimental group - mean age 31.2 years). A control group of 20 English native speakers (14 Americans, 1 British, 5 Australians - mean age 35 years) also took part of the study.

\section{Materials}

We employed an acceptability judgment task (GASS; MACKEY, 2005), representing in this study a measure of both learnability and generalization of patterns. The acceptability judgment task is a methodological procedure employed in many other studies of L2 argument structure acquisition (WHITE, 2003). Our version of the task (Fig. 1) consisted of 16 sets of two sentences which expressed the same event through either a non-dativized or a dativized double object construction. The following verbs were selected for the experimental task: give, hand, find, buy, tell, teach, make, build, offer, promise, and bring, all of them verbs that typically participate in the dative alternation.

Each sentence was rated according to a 5-point rating scale, an interval scale commonly used in syntax research (JOHNSON, 2008). As Fromkin (2000) points out, the task of judging whether a sentence is "correct" or "wrong" can be difficult, and an interval scale can help speakers rate sentences they do not think are likely to hear but do not find completely unacceptable, for example. To address this issue, participants were asked to assign one of the following values to each sentence: 1 = completely unacceptable, $2=$ somewhat unacceptable, 3 = no definite opinion, 4 = maybe acceptable, $5=$ absolutely acceptable.

3 English Placement Test. Oxford University Language Centre (2012). 


\section{RATE THE SENTENCES BELOW FROM 1 TO 5. There are no right or wrong answers. We want to learn your spontaneous feelings about the sentences. You don't need to think too long about each one.}

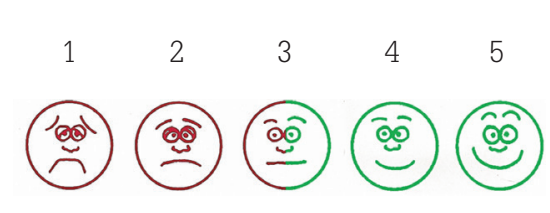

1: completely unacceptable

2: somewhat unacceptable

3: no definite opinion

4: maybe acceptable

5: absolutely acceptable

1) a) ( ) John told a story to Mark.

b) ( ) John told Mark a story.

3) a) ( ) John taught English to David.

b) ( ) John taught David English.

5) a) ( ) Mary me taught English.

b) ( ) Mary taught me English.

7) a) ( ) James me brought flowers.

c) ( ) James brought me flowers.

9) a) ( ) Laura made a cake for Mary.

b) ( ) Laura made Mary a cake.

11) a) ( ) James brought flowers to Lucy.

b) ( ) James brought Lucy flowers.

13) a) ( ) John bought a dress for me.

b) ( ) John bought me a dress.

15) a) ( ) John bought a dress for Mary.

b) ( ) John bought Mary a dress.
2) a) ( ) Mary gave a book to me.

b) ( ) Mary gave me a book.

4) a) ( ) I promised the book to David.

b) ( ) I promised David the book.

6) a) ( ) Peter gave money to John.

b) ( ) Peter gave John money.

8) a) ( ) Kevin built a doll's house for Mary.

b) ( ) Kevin built Mary a doll's house.

10) a) ( ) Lucy offered coffee to Mary.

b) ( ) Lucy offered Mary coffee.

12) a) ( ) Paul handed the car key to John.

b) ( ) Paul handed John the car keys.

14) a) ( ) Mary me told a story.

b) ( ) Mary told me a story.

16) a) ( ) Sarah finally found a pink dress for Mary.

b) ( ) Sarah finally found Mary a pink dress.

Source: Own elaboration.

\section{Data analysis}

The analysis of the data collected in this study was first aimed at describing the tendencies of each group's acceptability ratings of the sentences, which were categorized into 4 groups (Tableau 1). To do that, we performed an analysis of the distribution of ratings for each sentence in each group. As an example, one can see in table 1 the distribution of ratings for the sentence ditransitive/full NP/ 
teach found among the beginning experimental group. Rating (3) - no definite opinion - occurred as fewer than $10 \%$ of all ratings. Therefore, it was considered irrelevant for the analysis and discussion of data.

Tableau 1 - Categories of analysis

\begin{tabular}{|l|l|}
\hline Category & Example \\
\hline Ditransitive/full NP & Mark told John a story. \\
\hline Ditransitive/recipient pronoun & Mark told me a story. \\
\hline Pre-verbal recipient pronoun & Mark me told a story. \\
\hline Prepositional ditransitive & Mark told a story to John. \\
\hline
\end{tabular}

Source: Own elaboration.

Table 1 - Distribution of judgments on the sentence ditransitive/full NP/teach made by beginning learners

\begin{tabular}{|l|l|}
\hline GROUP 1 & \\
\hline Rating & Ditransitive/full NP/teach \\
\hline 1 & $48 \%$ \\
\hline 2 & $24 \%$ \\
\hline 4 & $16 \%$ \\
\hline 5 & $4 \%$ \\
\hline
\end{tabular}

Source: Own elaboration.

Another aim of the data analysis was to verify whether there were statistically significant differences between the experimental groups and the control group with regard to the acceptability of the sentences. To do that, "Fisher's ExactTest" was used (HATCH; LAZARATON, 1991). This is a non-parametric test that does not bear assumptions as to distributions - of judgments in our specific case - in the studied population. In other words, it does not assume normality of the data set. Fisher's Exact Test enables significance testing, i.e. it supports checking whether the distributions of answers (frequencies of ratings in our case) for each sentence in two groups are statistically similar $(p>.05)$ or not $(p<.05)$. For example, if the p-value obtained through the application of the Fisher's Exact Test when comparing the ratings on the sentence "John told Mary a story" by intermediate 
learners and native speakers of English is higher than $0.05(\mathrm{p}>.05)$, this means that the probability of acceptance of the verb tell in the ditransitive construction is similar in both groups.

The results obtained through the experimental task described above are shown in the following section.

\section{Results}

\section{Ditransitive/full NP category}

As expected, most beginning learners incorrectly rejected the ditransitive construction. The sum of judgments (1) - "completely unacceptable" - and (2) "maybe unacceptable" - for this group represented the majority of answers given to 9 out of the 11 ditransitive/full NP sentences presented in the experimental task (Graphic 1). As a result, beginning learners' judgments were significantly different from native speakers' judgments across for all verbs (p. <.001). This is very robust evidence that the beginning learners differed from native speakers in their acceptance of the ditransitive/full NP sentences.

Graphic 1 - Acceptability ratings of (1) - completely unacceptable - and (2) - maybe unacceptable - in the beginning experimental group on each ditransitive/full NP sentence

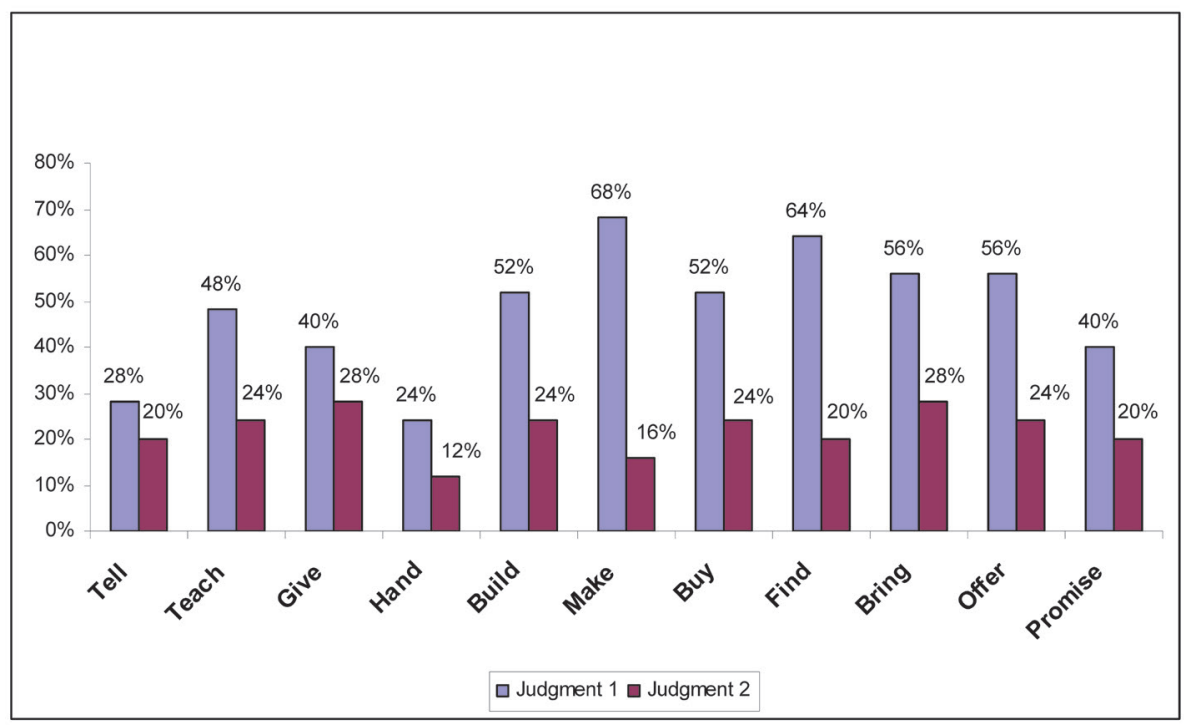

Source: Own elaboration. 
In the intermediate experimental group, we observed that more learners accepted the ditransitive construction with ratings of (4) and (5) (Graphic 2). However, this increase in the acceptability of the ditransitive construction did not reach significance $(p<.05)$, as the results of the Fisher's Exact Test show differences between the intermediate learners and the native speakers of English with regard to all ditransitive/full NP sentences except tell $(\mathrm{p}=.52)$.

Graphic 2 - Distribution of ratings of intermediate learners on each ditransitive/full NP sentence

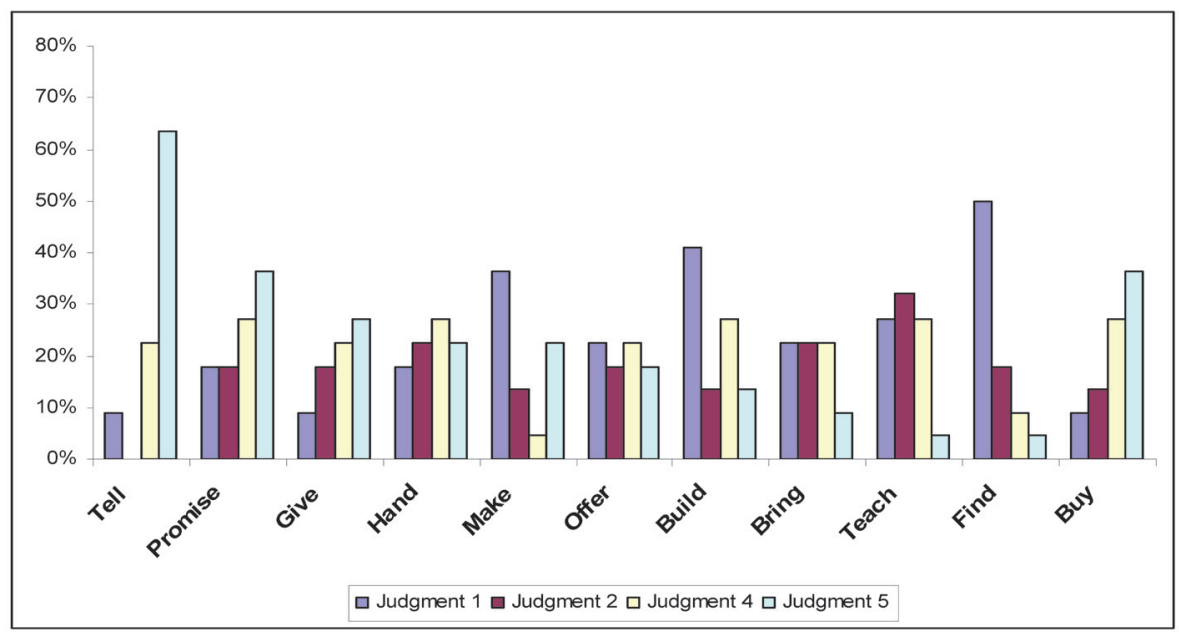

Source: Own elaboration.

At the advanced level of proficiency, most subjects accepted the ditransitive/ full NP sentences (Graphic 3), displaying the native speaker pattern. Therefore, the proficient English/L2 speakers were statistically similar $(p>.05)$ to the native speakers of English in relation to all those sentences. 
Graphic 3 - Distribution of ratings of advanced

learners for each ditransitive/full NP sentence

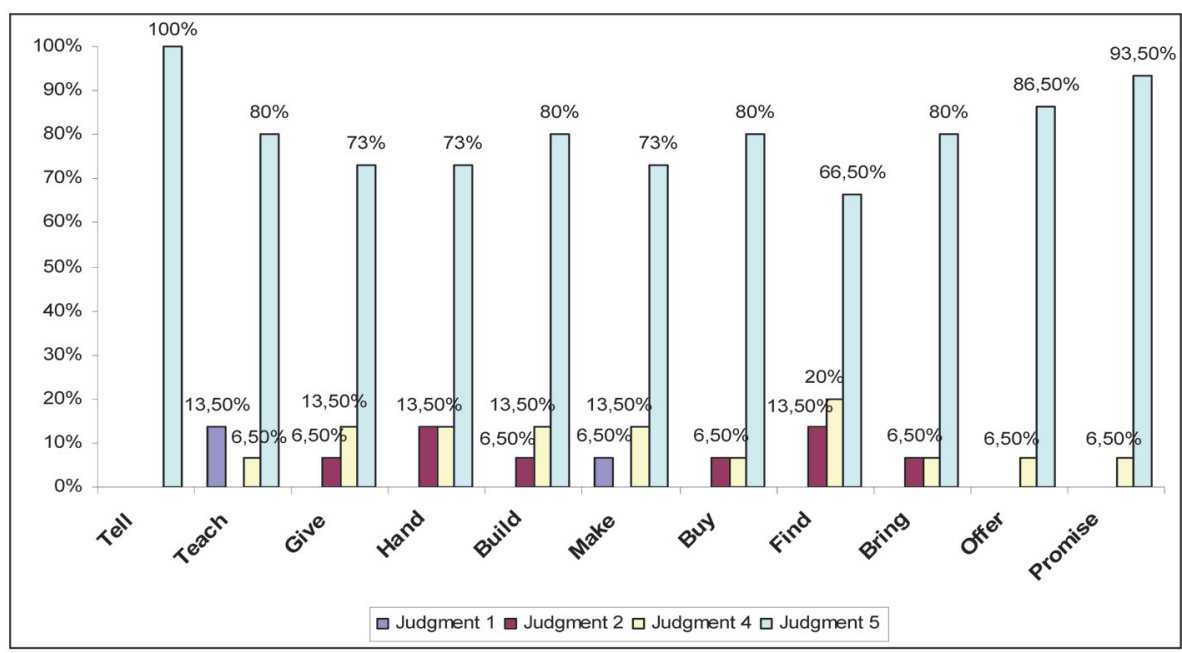

Source: Own elaboration.

Next, we contrast ratings on ditransitive/ full NP sentences and ditransitive/ recipient pronoun sentences.

\section{Ditransitive/recipient pronoun category}

The hypothesis raised about the acquisition of the dativized pronoun $<$ recipient> by Brazilian learners is repeated below:

Hypothesis: Due to analogy between sentences like Ele deu-me um livro in Brazilian Portuguese and He gave me a book in English, the dativized pronoun <recipient> will not impose learning difficulties for Brazilian learners of English.

The data collected showed that the subjects did rate ditransitive sentences more acceptable when the <recipient> argument was expressed by a pronoun. Table 1 contrasts ratings of the beginning group on ditransitive/full NP sentences and ditransitive/recipient pronoun sentences. 
Table 2 - Comparison between distributions of ratings of beginning learners on ditransitive/ full NP sentences (N) and ditransitive/recipient pronoun sentences $(\mathrm{P})$

\begin{tabular}{ccccccc}
\hline Judgement & Tell/N & Tell/P & Teach/N & Teach/P & Buy/N & Buy/P \\
1 & $28 \%$ & $0 \%$ & $48 \%$ & $8 \%$ & $52 \%$ & $12 \%$ \\
2 & $20 \%$ & $0 \%$ & $24 \%$ & $4 \%$ & $24 \%$ & $12 \%$ \\
4 & $16 \%$ & $\mathbf{2 8 \%}$ & $16 \%$ & $44 \%$ & $12 \%$ & $\mathbf{5 2 \%}$ \\
5 & $36 \%$ & $\mathbf{6 8 \%}$ & $4 \%$ & $40 \%$ & $8 \%$ & $\mathbf{2 0 \%}$ \\
\hline Judgement & Give/N & Give/P & Bring/N & Bring/P & & \\
1 & $40 \%$ & $0 \%$ & $56 \%$ & $4 \%$ & & \\
2 & $28 \%$ & $12 \%$ & $28 \%$ & $20 \%$ & & \\
4 & $20 \%$ & $20 \%$ & $8 \%$ & $40 \%$ & & \\
5 & $8 \%$ & $68 \%$ & $0 \%$ & $32 \%$ & & \\
\hline
\end{tabular}

Source: Own elaboration.

Although the beginning learners rated ditransitive/recipient pronoun sentences higher on the acceptability scale than the ditransitive/ full NP sentences, their acceptability ratings on the ditransitive/recipient pronoun sentences were statistically different $(\mathrm{p}<.05)$ from those of native speakers of English.

Likewise beginning learners, intermediate learners accepted the ditransitive/ recipient pronoun sentences more than the ditransitive/full NP sentences:

Table 3 - Comparison between frequency of ratings of the intermediate group for ditransitive/full NP (N) and ditransitive/ recipient pronoun $(\mathrm{P})$ sentences which have the same verbs

\begin{tabular}{ccccccc}
\hline Judgment & Tell/N & Tell/P & Teach/N & Teach/P & Buy/N & Buy/P \\
1 & $2(9 \%)$ & $0 \%$ & $6(27 \%)$ & $1(4,5 \%)$ & $2(9 \%)$ & $1(4.5 \%)$ \\
2 & $0 \%$ & $0 \%$ & $7(32 \%)$ & $2(9 \%)$ & $3(13,5 \%)$ & $0 \%$ \\
4 & $5(22.5 \%)$ & $1(4.5 \%)$ & $6(27 \%)$ & $2(9 \%)$ & $6(27 \%)$ & $9(41 \%)$ \\
5 & $\mathbf{1 4 ( 6 3 . 5 \% )}$ & $\mathbf{2 1 ( 9 5 \% )}$ & $\mathbf{1 ( 4 . 5 \% )}$ & $\mathbf{1 6}(\mathbf{7 2 . 5} \%)$ & $\mathbf{8 ( 3 6 . 5 \% )}$ & $\mathbf{1 1 ( 5 0 \% )}$ \\
\hline Judgment & Give/N & Give/P & Bring/N & Bring/P & & \\
1 & $2(9 \%)$ & $0 \%$ & $5(22.5 \%)$ & $0 \%$ & & \\
2 & $4(18 \%)$ & $0 \%$ & $5(22.5 \%)$ & $2(9 \%)$ & & \\
4 & $5(22.5 \%)$ & $1(4.5 \%)$ & $5(22.5 \%)$ & $7(32 \%)$ & & \\
5 & $\mathbf{6 ( 2 7 \% )}$ & $\mathbf{2 1 ( 9 5 \% )}$ & $\mathbf{2 ( 9 \% )}$ & $\mathbf{1 3 ( 6 0 \% )}$ & & \\
\hline
\end{tabular}

Source: Own elaboration. 
When intermediate experimental group was compared to the control group, the following results were obtained. Statistical similarities between the two groups were found in relation to the sentences with the verbs tell $(p=1.00)$, teach $(\mathrm{p}=.086)$, and give $(\mathrm{p}=1.00)$. However, intermediate learners still differed from the native speakers of English in relation to the ditransitive/recipient pronoun sentences with the verbs buy $(\mathrm{p}=.017)$ and bring $(\mathrm{p}=.003)$, which were more widely accepted by the control group.

At the advanced level of proficiency, the acceptance of the ditransitive/ recipient pronoun sentences was similar to the acceptance of the ditransitive/full NP sentences (Table 3). Once advanced learners displayed native speaker pattern, they were statistically similar ( $p>.05$ ) to native speakers of English in relation to all ditransitive/recipient pronoun sentences in the experiment.

Table 4 - Comparison between frequency of ratings of advanced learners on ditransitive/full NP (N) and ditransitive/recipient pronoun $(\mathrm{P})$ sentences which have the same verbs

\begin{tabular}{ccccc}
\hline Judgment & Tell/N & Tell/P & Teach/N & Teach/P \\
1 & $0 \%$ & $0 \%$ & $13.50 \%$ & $0 \%$ \\
2 & $0 \%$ & $0 \%$ & $0 \%$ & $0 \%$ \\
4 & $0 \%$ & $0 \%$ & $6.50 \%$ & $0 \%$ \\
5 & $\mathbf{1 0 0 \%}$ & $\mathbf{1 0 0} \%$ & $\mathbf{8 0} \%$ & $\mathbf{1 0 0 \%}$ \\
\hline Judgment & Buy/N & Buy/P & Bring/N & Bring/P \\
1 & $0 \%$ & $0 \%$ & $0 \%$ & $0 \%$ \\
2 & $6.50 \%$ & $0 \%$ & $6.50 \%$ & $0 \%$ \\
4 & $6.50 \%$ & $0 \%$ & $6.50 \%$ & $0 \%$ \\
5 & $\mathbf{8 0 \%}$ & $100 \%$ & $\mathbf{8 0} \%$ & $100 \%$ \\
\hline Judgment & Give/N & Give/P & & \\
1 & $0 \%$ & $0 \%$ & & \\
2 & $6.50 \%$ & $0 \%$ & & \\
4 & $13.50 \%$ & $0 \%$ & & \\
5 & $\mathbf{7 3 . 5 0 \%}$ & $\mathbf{1 0 0} \%$ & & \\
\hline
\end{tabular}

Source: Own elaboration.

So far we have seen that for the ditransitive construction to be widely accepted by Brazilian beginning learners of English, the NP <recipient $>$ has to be expressed by a pronoun. When the $<$ recipient $>$ argument is expressed by a full $<\mathrm{NP}\rangle$, the broad acceptance of this construction occurs at the advanced level of proficiency in the target language. In the next section, we show what happens when the $<$ recipient $>$ argument is expressed by a pronoun in pre-verbal position. 


\section{Pre-verbal <recipient $>$ pronoun category}

Regarding the acceptance of sentences in which the <recipient $>$ argument is expressed by a pronoun placed before the verb, we hypothesized as follows:

Hypothesis: The expression of the <recipient> pronoun in pre-verbal position, *He me gave a book/Ele me deu um livro, which is possible in Brazilian Portuguese but ungrammatical English, may be transferred to the interlanguage of beginning learners.

This hypothesis was rejected, as the ratings of the beginning experimental group on pre-verbal recipient pronoun sentences show.

Graphic 4 - Distribution of ratings of beginning learners on each pre-verbal recipient pronoun sentence

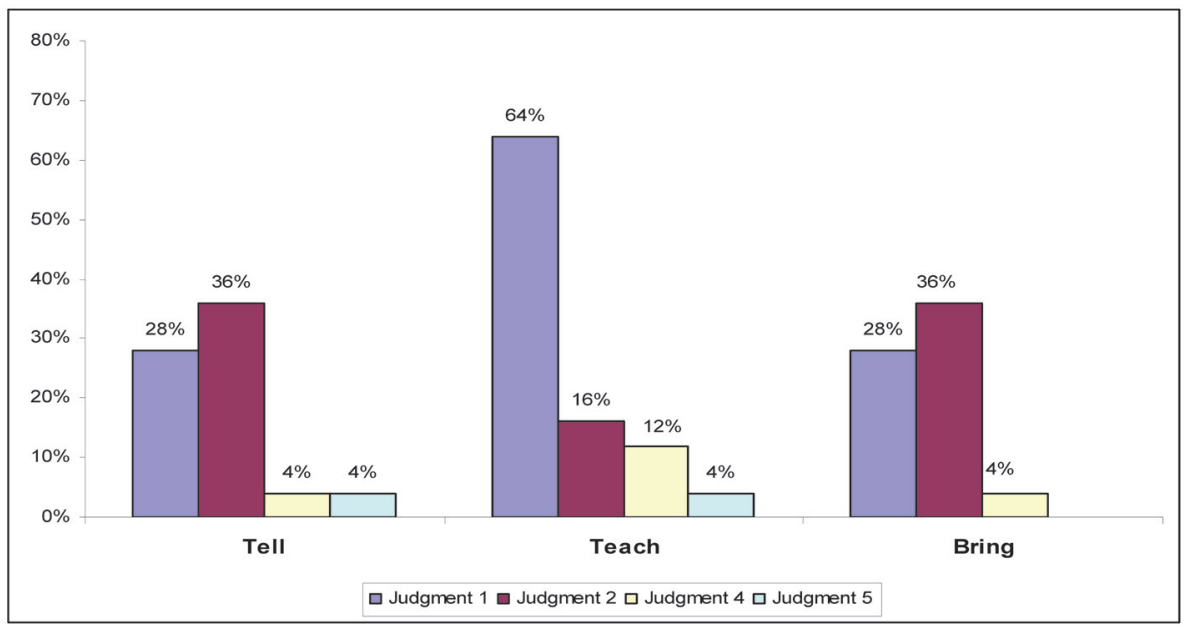

Source: Own elaboration.

The same rejection of the pre-verbal pronoun categories was found in the intermediate and advanced experimental groups. We move on now to the results of a category wherein there is a syntactic match between English and Portuguese, the prepositional ditransitive category (John gave a book to Mary / João deu um livro para Maria). 


\section{Prepositional ditransitive category}

All groups accepted most sentences displaying the prepositional ditransitive construction, as table 12 shows:

Table 5 - Frequency of acceptability rating of 5 on prepositional ditransitive sentence of all experimental groups $(1,2,3)$ and of the control group (4)

\begin{tabular}{lccccccc}
\hline Category & Tell & Teach & Give & Hand & Build & Make & Buy \\
Group 1 & $\mathbf{6 4 \%}$ & $\mathbf{5 6 \%}$ & $\mathbf{5 6 \%}$ & $\mathbf{4 8 \%}$ & $\mathbf{8 4 \%}$ & $\mathbf{9 2 \%}$ & $\mathbf{8 4 \%}$ \\
Group 2 & $36.50 \%$ & $\mathbf{7 2 . 5 0 \%}$ & $\mathbf{7 7 \%}$ & $\mathbf{6 8 \%}$ & $\mathbf{8 6 . 5 0 \%}$ & $\mathbf{8 2 \%}$ & $\mathbf{7 2 . 5 0 \%}$ \\
Group 3 & $33.50 \%$ & $\mathbf{7 3 . 5 0 \%}$ & $\mathbf{6 6 . 5 0 \%}$ & $\mathbf{8 6 . 5 0 \%}$ & $\mathbf{9 3 . 5 0 \%}$ & $\mathbf{8 6 . 5 0 \%}$ & $\mathbf{8 6 . 5 0 \%}$ \\
Group 4 & $\mathbf{5 5 \%}$ & $\mathbf{8 0 \%}$ & $\mathbf{9 5 \%}$ & $\mathbf{8 5 \%}$ & $\mathbf{1 0 0 \%}$ & $\mathbf{9 0 \%}$ & $\mathbf{8 5 \%}$ \\
\hline Category & Find & Bring & Offer & Promise & & & \\
Group 1 & $\mathbf{7 6 \%}$ & $\mathbf{8 4 \%}$ & $\mathbf{5 2 \%}$ & $\mathbf{4 8 \%}$ & & & \\
Group 2 & $\mathbf{9 1 \%}$ & $\mathbf{9 1 \%}$ & $\mathbf{7 7 \%}$ & $45.50 \%$ & & & \\
Group 3 & $\mathbf{1 0 0 \%}$ & $\mathbf{8 0 \%}$ & $\mathbf{6 6 . 5 0 \%}$ & $\mathbf{5 3 \%}$ & & & \\
Group 4 & $\mathbf{9 5 \%}$ & $\mathbf{8 0 \%}$ & $\mathbf{8 5 \%}$ & $\mathbf{8 5 \%}$ & & & \\
\hline
\end{tabular}

Source: Own elaboration.

Beginning learners were statistically similar to native speakers of English in regard to 7 instances of the prepositional ditransitive category: teach $(p=.483)$, build $(p=.117)$, make $(p=1.00)$, buy $(p=1.00)$, find $(p=.205)$, bring $(p=.816)$, and offer $(p=.108)$. At the intermediate level of proficiency, learners displayed native speaker pattern in relation to all prepositional ditransitive sentences but the one with the verb promise $(\mathrm{p}=.034)$. Few acceptability ratings of advanced learners on the prepositional ditransitive sentences were different from 5 . As a result, the group of proficient English/L2 speakers was statistically similar to the control group in relation to all those sentences but the one with verb tell $(p=.04)$.

We turn now to the discussion of the results described above.

\section{Discussion}

\section{Ditransitive/full NP category}

The tendency towards the rejection of ditransitive/full NP sentences found in the beginning experimental group indicates that the ditransitive construction is not part of the interlanguage grammar of those learners. It can be argued that beginning learners have not had enough experience with the target language to have noticed and learned a construction that is not licensed in standard Brazilian 
Portuguese. A gradual increase in the acceptance of ditransitive/full NP sentences was found as we moved to the intermediate experimental group. However, results of this group do not allow the conclusion that Brazilian intermediate learners of English have already acquired the ditransitive construction. Rather, we suggest that intermediate students' acceptability ratings of (4) and (5) represent "itembased knowledge", that is, knowledge about the syntactic behavior of individual lexical items (ELLIS, 1999; TOMASELLO, 2000; GOLDBERG, 2006). Evidence of the acquisition of the English ditransitive construction by Brazilian learners was only found at the advanced level of proficiency in the target language, where there was a broad acceptance of all ditransitive/full NP sentences.

\section{Ditransitive/recipient pronoun category}

We saw that the acceptance of the ditransitive construction by beginning and intermediate Brazilian learners of English is higher when the < recipient $>$ argument is expressed by a pronoun. There are two possible explanations for this finding. On the one hand, one can argue that learners were exposed to a greater amount of occurrences of the ditransitive construction with the <recipient> argument expressed by a pronoun. On the other hand, one can claim that learners were influenced by Brazilian Portuguese, since the word-by-word translation of "John told me a story" into Portuguese is "John contou-me uma história", a sentence that belongs to standard Portuguese. We consider that an interaction between these two factors (influence of L1 and L2 input frequency) is also possible.

\section{Pre-verbal < recipient > pronoun category}

Results showing that most learners of all proficiency levels rejected the preverbal <recipient> pronoun sentences allow the conclusion that the expression of transfer events with the <recipient> pronoun placed before the verb, which is possible in Brazilian Portuguese, is not one of the hypotheses raised by Brazilian learners of English about the organization of the target language. This finding is relevant, as it clearly opposes to a view of language transfer as an unconstrained phenomenon. We find it worthy emphasizing that the participants of our study who were learners at a very early stage of English L2 and who rejected sentences with pre-verbal <recipient> pronoun in English actually demonstrated an early departure of a syntactic realization of argument structure that is quite productive in their L1. In view of the proposal that linguistic transfer is indeed a selective process, perhaps modulated by psychotypological perceptions (KELLERMAN, 1979, 1983; ROTHMAN; CABRELLI AMARO, 2010), in which features tacitly or overtly perceived as language-specific are not likely to be transferred, we consider 
that our finding may be a case of such mechanism in action. Even though we do not have systematic data to fully support our suggestion, we find it plausible to hypothesize that the absolute lack of pre-verbal pronouns in English input may have interacted with some level of perception of the optionality and restrictions of the same structure in Portuguese, in such a way that those learners may have considered the pre-verbal <recipient> pronoun argument to be too "Portugueselike" to be accepted in the L2.

\section{Prepositional ditransitive category}

There was a broad acceptance of the prepositional ditransitive categories by learners of all English proficiency levels. This made learners statistically similar to native speakers of English when dealing with a phrasal pattern which is present both in their L1and in the target language regardless of their proficiency level in the L2.

The comparison between the acceptability ratings of learners on the ditransitive sentences and the prepositional ditransitive sentences provides evidence that Brazilian learners of English acquire the prepositional ditransitive construction before the ditransitive construction. It is interesting to notice that a similar result was found by Mazurkewich (1984) when she studied the acquisition of English double object constructions by native speakers of French. She argues that this sequence of acquisition will hold true for all second language learners of English due to the fact that the prepositional ditransitive structure is unmarked, that is, part of core grammar, and should be acquired before marked structures (ditransitive construction), which are considered to be peripheral rules of the core grammar. Following Kellerman (1983), however, we suggest that effects of cross-linguistic influence (positive transfer) are enough to explain the sequence of acquisition of the English ditransitive constructions by both Brazilian and French learners, since the earlier acquisition of the prepositional ditransitive construction can be predicted by a simple contrastive analysis of L1 and L2.

\section{Conclusion}

This study aimed at shedding light on the acquisition of the English double object constructions by Brazilian learners of English, with an explicit focus on the breadth of occurrence of cross-linguistic influences on L2 grammatical knowledge. In summary, our findings render evidence that the participants were not guided by over-arching semantic and syntactic categories in the early stages of their knowledge of such constructions in their L2. Also, our findings provide evidence that the participants' L1 influenced the form the expression of transfer events 
took in their L2, but at the same time we found evidence that L1 influence was not at all an unconstrained mechanism, not even for those participants who had the least proficiency as users of English L2.

Analysis of the data on the ditransitive-full NP sentences showed that beginning and intermediate learners displayed limited acceptance of verbs in the ditransitive construction. It was also found that the verbs accepted in this construction varied a lot among learners of the same group. Following proposals by Ellis (1999), we believe that such variation may be evidence of an item-based learning of this construction, at least in early L2 acquisition of the ditransitive construction in English. This has important consequences for theories of L2 learning, as it supports perspectives proposing that learners are initially driven by factors such as the frequency of items in the L2 input received by them, rather than by broad, higher-order semantic or syntactic categories. It may even be also the case that frequency of input is not alone as the cornerstone for the acquisition of the construction, as the variability of learning we observed may have been also modulated by the perceived subjective and personal relevance of the contexts in which they occur by each individual learner, as suggested by Campbell and Tomasello (2001). Nevertheless, a significant change was observed in the performance of learners at the advanced level of English proficiency, as they accepted the ditransitive-full NP sentences in a statistically similar way to native speakers of English. This result indicates that ultimately the ditransitive construction is represented as a general, broad and general category affecting a class of semantically related verbs, and being represented as a part of the L2 grammar of those learners.

As we moved into the analysis of the ditransitive-recipient pronoun category, we saw that the expression of the <recipient $>$ argument by a pronoun did favor the acceptance of the ditransitive construction by the learners, especially in the beginning and intermediate experimental groups. We raised two explanatory hypotheses for this: (1) learners made an analogy between sentences such as "Maria deu-me um livro" and "Mary gave me a book", that is, they were influenced by their mother tongue; (2) during their experience with the L2 input, learners witnessed a significantly greater number of occurrences of the ditransitive construction with the argument <recipient> expressed by a pronoun rather than by another NP. An interaction between L1 influence and frequency effects was also considered.

Although the comparison between the performances of native speakers of different mother tongues in the same experimental task is needed to draw definitive conclusions about the influence of L1 on the interlanguage (ODLIN, 1989), some evidence of this influence was found in this study through the comparison between the acceptability ratings of the same learners on different sentence 
patterns. For instance, beginning learners tended to accept the prepositional ditransitive construction - present in standard Portuguese - much more than the ditransitive construction - absent in standard Portuguese. It is noteworthy that research in the acquisition of English as an L1 by children shows that the ditransitive construction usually appears earlier in the speech of children rather than its prepositional paraphrase in the expression of events of transfer of possession (CAMPBELL; TOMASELLO, 2001). The fact that our data demonstrate the opposite direction and the fact that the direction we found is so remarkably correspondent to a structure of our participants' L1 are indicators that our results represented L1 influences on the L2.

Notwithstanding, of particular interest to theoretical models of L1 influences on L2 language learning is the fact that our findings also demonstrate that although language transfer is a highly plausible cognitive mechanism affecting the acquisition of the double object construction of our participants, such mechanism is subtle. Our data also supports the view that transfer in L2 learning is a selective process, as testified by the rejection of <recipient $>$ pronoun in pre-verbal position in English by Brazilian Portuguese learners of L2 English at early stages of development in their interlanguage grammar despite the fact that such word order is perfectly possible in their L1. In other words, activation of L1 knowledge does not seem to be an automatic and mandatory process in L2 performance, neither is such activation an all-or-nothing procedure. Rather, it seems that L2 learners employ some sort of decision making process regarding which features from their L1 are shared by their L2.

As seen above, we are inclined to interpret the selectivity of L1 transfer we observed in light of the psychotypology hypothesis, as it can be the case that the participants of our study rejected the <recipient> pronoun in pre-verbal position in their L2 because this construction could be perceived as too specific of their L1, especially in view of the optionality, the grammatical constraints, and possibly the pragmatic markedness of this pattern in BP. This is convergent with the proposal of a psychotypological modulation for language transfer put forward by Kellerman (1979, 1983), also discussed by Rothman and Cabrelli Amaro (2010). However, to what extent such selectivity on the activation of L1 knowledge during L2 use is dependent on features of the L2 input learners are exposed to or whether or not such selectivity would be present in the performance of a language task with different characteristics are very important questions that the present study was not fit to address. Such are questions that must be pursued for our findings to be fully integrated not only into a model of second language learning, but especially in a model of bilingual language processing, as our results can have implications for the understanding of the activation and inhibition mechanisms that allow users of more than one language to manage the different sets of linguistic representations they have at their disposal to 
perform communication. These are matters that certainly motivate us for further investigation of the object of the present study.

ZARA, J. V.; SOUZA, R. A. de; OLIVEIRA, F. L. P. de. Transferência seletiva na aquisição das construções de objeto duplo do inglês por aprendizes brasileiros. Conceptual integration in the description of grammatical phenomena in Portuguese. Alfa, São Paulo, v.57, n.2, p.519-544, 2013.

- RESUMO: Neste trabalho, investigamos a aquisição das construções de objeto duplo do inglês (GOLDBERG, 1995) por aprendizes brasileiros. Partimos da hipótese de que, devido à influência da primeira língua (L1), a construção ditransitiva preposicionada (John gave a book to Mary) será adquirida primeiro, enquanto a construção ditransitiva (John gave Mary a book) fará parte da interlíngua (SELINKER, 1972) dos aprendizes apenas no nível avançado de proficiência na língua-alvo. Levantamos também a hipótese de que aprendizes podem transferir (ODLIN, 1989) o pronome objeto em posição pré-verbal de sua L1 para a interlíngua nos estágios iniciais de acquisição da L2 (João me deu um livro / *John me gave a book). Testamos nossas hipóteses através da comparação das performances de três grupos de aprendizes brasileiros (iniciantes, intermediários e avançados) com um grupo de falantes nativos do inglês na realização de uma tarefa de julgamento de aceitabilidade de sentenças, utilizada como medida de aprendibilidade e generalização. Os resultados obtidos confirmam a nossa hipótese sobre a ordem de aquisição das construções de objeto duplo do inglês por falantes nativos do português brasileiro e indicam que a influência da L1 no desenvolvimento da interlíngua dos aprendizes ocorre de forma seletiva, assim como propõe Kellerman (1983).

- PALAVRAS-CHAVE: Influência translinguística. Transferência seletiva. Construções de objeto duplo. Bilinguismo.

\section{REFERENCES}

BALCOM, P. Why is this happened? passive morphology and unaccusativity. Second Language Research, Londres, v.13, n.1, p.1-9, jan. 1997.

BECHARA, E. Moderna gramática portuguesa. Rio de Janeiro: Lucerna, 2003.

CAMPBELL,A.; TOMASELLO, M. The acquisition of English dative constructions. Applied Psycholinguistics, Cambridge, v.22, p.253-267, 2001.

CHOMSKY, N. Lectures on government and binding. Dordrecht: Foris, 1981.

CULLICOVER, P. Natural language syntax. Oxford: Oxford University Press, 2009.

ELLIS, R. The study of second language acquisition. 2.ed. Oxford: Oxford University Press, 2008.

. Item versus system learning: explaining free variation. Applied LinguisticS, Oxford, v.20, p.460-480, 1999. 
FROMKIN,V. (Ed.). Linguistics: an introduction to linguistic theory. Massachusetts: Blackwell, 2000.

GASS, S.; MACKEY, A. Second language research: methodology and design. Mahwah: Lawrence Erlbaum, 2005.

GOLDBERG, A. Constructions at work. Oxford: Oxford University Press, 2006.

Constructions: a construction grammar approach to argument structure. Chicago: University of Chicago Press, 1995.

GOMES, C. Dative alternation in Brazilian Portuguese: typology and constraints. Language Design Journal of Theoretical and Experimental Linguistics, Granada, v.5, p.67-78, 2003.

HATCH, E. M.; LAZARATON, A. The research manual: design and statistics for applied linguistics. Boston: Heinle \& Heinle, 1991.

HOVAV, M. R.; LEVIN, B. The English dative alternation: the case for verb sensitivity. Journal of Linguistics, Cambridge, v.44, p.126-167, 2008.

JACKENDOFF, R. Foundations of language. Oxford: Oxford University Press, 2002. . Semantic interpretation in generative grammar. Cambridge: MIT Press, 1972.

JACKENDOFF, R.; CULLICOVER, P. Simpler syntax. Oxford: Oxford University Press, 2006.

JOHNSON, K. Quantitative methods in Linguistics. Oxford: Blackwell, 2008.

JUFFS, A. An overview of the second language acquisition of links between verb semantics and morphosyntax. In: ARCHIBALD, J. (Ed.). Second language acquisition and linguistic theory. Oxford: Blackwell, 2000. p.187-227.

Some effects of first language argument structure and morphosyntax on second language sentence processing. Second Language Research, Londres, v.14, n.4, p.406-424, 1998.

KELLERMAN, E. Now you see it, now you don't. In: GASS, S.; SELINKER, L. (Ed.). Language transfer in Language Learning. Rowley: Newbury House Publishers, 1983. p.112-134.

.Transfer and non-transfer: where are we now? Studies in Second Language Acquisition, Bloomington, v.2, p.37-57, 1979.

LEVIN, B.; HOVAV, M. R. Argument realization. Cambridge: Cambridge University Press, 2005. 
MAZURKEWICH, T. The acquisition of the dative alternation by second language learners and linguistic theory. Language Learning, Ann Arbor, v.34, n.1, p.91-108, 1984.

MONTRUL, S. Psycholinguistic evidence for split intransitivity in Spanish second language acquisition. Applied Psycholinguistics, Cambridge, v.25, p.239-267, 2004.

ODLIN, T. Language transfer. Cambridge: Cambridge University Press, 1989.

OSHITA, H. What is happened may not be what appears to be happening: a corpus study of 'passive' unaccusatives in L2 English. Second Language Research, Londres, v.16, p.293-324, 2000.

OXFORD UNIVERSITY LANGUAGE CENTRE. English Placement Test. Available at: <http://www.lang.ox.ac.uk/courses/tst_placement_english.html>. Access in: 03 fev. 2012.

ROTHMAN, J.; CABRELLIAMARO, J. What variables condition syntactic transfer? a look at the L3 initial state. Second Language Research, Londres, v.26, p.189-218, 2010.

SALAMOURA, A.; WILLIAMS, J. N. Processing verb argument structure across languages: evidence for shared representations in the bilingual mental lexicon. Applied Psycholinguistics, Cambridge, v.28, p.627-660, 2007.

SCHACHTER, J. A new account of language transfer. In: GASS, S.; SELINKER, L. (Ed.). Language transfer in language learning. 2.ed. Amsterdam: John Benjamins, 1993. p.98-111.

SCHER, A. As construções com dois complementos no inglês e no português do Brasil: um estudo sintático comparativo. Sínteses, Campinas, v.2, p.347-355, 1996.

SELINKER, L. Interlanguage. International Review of Applied Linguistics, Heidelberg, v.10, p.209-231, 1972.

SOUZA, R. A. Argument structure in L2 acquisition: language transfer re-visited in a syntax and semantics perspective. Ilha do Desterro, Florianópolis, n.60, p.153-188, 2011.

SOUZA, R. A.; OLIVEIRA, F. L. P. Is knowledge of a non-dominant L2 activated by bilinguals using their dominant L1? Insights from an on-line psycholinguistic study. Organon, Porto Alegre, n.51, p.103-128, 2011.

TOMASELLO, M. The item-based nature of children's early syntactic development. Trends in Cognitive Sciences, Oxford, v.4, p.156-163, 2000.

VANVALIN, R.; LAPOLLA, R. Syntax. structure, meaning and function. Cambridge: Cambridge University Press, 1997. 
VILELA, A. C.; OLIVEIRA, F. L. P. "I cut my hair" e "I did my nails": evidência de transferência linguística na interlíngua de falantes brasileiros aprendizes de inglês como segunda língua? Trabalhos de Linguística Aplicada, Campinas, v.49 n.1, p.223-239, 2010.

WHITE, L. Second language acquisition and universal grammar. Cambridge: Cambridge University Press, 2003.

Recebido em agosto 2012

Aprovado em novembro de 2012 